Bull.Fac, Agric.,Cairo Univ.,62:378-386 (2011).

\title{
EFFECT OF SALINITY ON GROWTH AND CHEMICAL CONSTITUENTS OF Moringa oleifera LAM.
}

(Received: 25. 5. 2011)

\author{
By \\ R. S. El-Dabh, M. A. El-Khateeb, A. A. M. Mazher* and A. A. Abd El-Badaie* \\ Ornamental Horticulture Department, Faculty of Agriculture, Cairo University. \\ * Ornamental Plants and Woody Trees Department, National Research Centre, Dokki, Egypt.
}

\begin{abstract}
Moringa oleifera, Lam., commonly named horseradish or drumstick tree, is cultivated for multiple purposes because all its parts including seeds, stems, shoots, leaves, flowers, fruits and roots are useful. The objective of this study was to evaluate salt tolerance of Moringa oleifera during its early growth stage. A pot experiment was conducted in the greenhouse during two successive seasons 2005/2006 and 2006/2007; at the Nubaria Research and Production Station. Equal amounts of sodium chloride and calcium chloride (w: $\mathrm{w}, 1: 1$ ) were mixed with sandy loam soil at six rates: $0.0,0.2,0.4,0.6,0.8$ and 1.0 $\%$.

Forty - day - old seedlings were planted and kept to grow for 18 months until recording the data. Young Moringa trees were affected by soil salinity at relatively high levels. Low salt concentrations slightly reduced growth, whereas increasing salinity decreased plant height, stem diameter, branch number, leaf number, and root length. High salinity had a detrimental effect on shoot and root dry weights, and pigment contents. Nitrogen, phosphorous, and potassium contents in all plant parts were greatly reduced under high salinity levels. Sodium content increased with increasing salinity and showed a higher accumulation in roots.
\end{abstract}

Key words: growth, Moringa oleifera, nutrients, salinity.

\section{INTRODUCTION}

Moringa oleifera, Lam. (syn. $M$. pterygosperma, Gaert.), commonly known as horseradish and drumstick tree, belongs to the family Moringaceae which consists of the single genus Moringa, comprising 10-14 species. The best-known species is $M$. oleifera, indigenous to northwest India; and widely cultivated in Philippines, Thailand, Malaysia, Pakistan and other tropical and subtropical areas in Central Asia, America and Africa (Morton, 1991; Ramachandran et al., 1980).

Moringa oleifera is often called " the miracle tree" because all its parts are useful. The seeds are used as a natural coagulant for raw water clarification, the powder of crushed seed kernels can leave water clear with $90-99 \%$ of the bacteria removed (Sutherland et al., 1989). The seeds are also used for oil productions; this oil is used in art, cosmetics and medicine; and can be consumed as food.

Most of the tree is edible; the leaves, young shoots, flowers and fruits can be used as vegetables or pickles; the tuberous root cores can be substituted for horseradish. Moreover, each part of $M$. oleifera is used in some type of native medicine such as fungicide, purgative, cardiac and circulatory stimulants (Morton, 1991, and Meitzner and Price, 1996).

Moringa oleifera can be easily propagated by seeds or cuttings, can tolerate a wide range of soil, and can resist long drought periods due to its long taproot.

The salt tolerance of Moringa oleifera was previously determined using rooted cuttings or seedlings (Valia et al., 1993), but no other data on salt tolerance of Moringa tree were available.

The present study was carried out to add more information concerning the effect of soil salinity on growth and constituents of Moringa oleifera tree during its early growth stage.

\section{MATERIALS AND METHODS}

The present study was carried out at the Ornamental Horticulture Department, Faculty of Agriculture, Cairo University; Giza, Egypt. The experimental work was carried out at the Research and Production Station of the National 
Research Centre (NRC) at Nubaria region.

A pot experiment was carried out during two successive seasons 2005/2006 and 2006/2007, aiming to find out the effect of soil salinity $(\mathrm{NaCl}$ $+\mathrm{CaCl}_{2} 1: 1$ by weight) on growth parameters and chemical constituents of Moringa oleifera Lam.

The seeds of Moringa oleifera (Lam.) which were obtained from Kom-Ombo tropical garden, Aswan, Egypt; were sown in seed beds (the germination of seeds reached 90 to $100 \%$ ), the seedlings were kept in a greenhouse until transplanting which occurred after 40 days (about $10-12 \mathrm{~cm}$ height).

The salts used in the experiment were: sodium chloride $(\mathrm{NaCl})$ and calcium chloride $\left(\mathrm{CaCl}_{2}\right)$; and were mixed with sandy loam soil, each pot contained $10 \mathrm{Kg}$ of a soil mixture.
Growth characters included the following parameters: plant height $(\mathrm{cm})$, stem diameter (mm), number of branches / plant, number of leaves / plant, root length $(\mathrm{cm})$, fresh and dry weight of shoots $(\mathrm{g})$ and fresh and dry weight of roots $(\mathrm{g})$.

\section{Chemical constituents}

Total chlorophyll and carotenoids mg / g F.W. were determined according to Nornai (1982); nitrogen content was determined by the modified micro-Kjeldahl method as described by Pregl (1945); phosphorus content was estimated using ammonium molybdate method according to Snell and Snell (1949); potassium was determined using flame photometer according to Chapman and Pratt (1961); sodium was determined according to the method described by Cottenie et

Table (A): Some physical and chemical properties of the used soil

\begin{tabular}{|c|c|c|c|c|c|c|}
\hline \multicolumn{5}{|c|}{ Particle size distribution } & \multirow{2}{*}{\multicolumn{2}{|c|}{ Field capacity (\%) }} \\
\hline Sand (\%) & \multicolumn{2}{|c|}{ Silt (\%) } & Clay (\%) & Soil Texture & & \\
\hline 70.8 & \multicolumn{2}{|c|}{25.6} & 3.6 & Sandy loam & \multicolumn{2}{|c|}{20.1} \\
\hline \multicolumn{7}{|c|}{ Chemical properties } \\
\hline $\mathrm{EC} \mathrm{dsm}^{-1}$ & \multicolumn{2}{|c|}{ pH (1:2.5) } & $\mathrm{CaCO}_{3}(\%)$ & O.M (\%) & \multicolumn{2}{|c|}{$\begin{array}{c}\text { Soluble Cobalt } \\
(\mathrm{ppm})\end{array}$} \\
\hline 1.26 & \multicolumn{2}{|c|}{7.9} & 3.57 & 0.23 & \multicolumn{2}{|c|}{0.49} \\
\hline \multicolumn{4}{|c|}{ Soluble Cations $\left(\mathrm{meq} \mathrm{L}^{-1}\right)$} & \multicolumn{3}{|c|}{ Soluble Anions $\left(\operatorname{meq} \mathbf{L}^{-1}\right)$} \\
\hline $\mathrm{Ca}^{++}$ & $\mathrm{Mg}^{++}$ & $\mathrm{K}^{+}$ & $\mathrm{Na}^{+}$ & $\mathrm{HCO}_{3}^{-}$ & $\mathrm{Cl}^{-}$ & $\mathrm{SO}_{4}^{--}$ \\
\hline \begin{tabular}{|l|l|}
2.4 & \\
\end{tabular} & 2.0 & 0.162 & 1.87 & 1.50 & 0.65 & 4.28 \\
\hline \multirow[t]{2}{*}{$\begin{array}{c}\text { Total N } \\
(\mathrm{mg} / \mathbf{1 0 0 g})\end{array}$} & \multicolumn{2}{|c|}{$\begin{array}{l}\text { Available } \\
\text { (mg/100g) }\end{array}$} & \multicolumn{4}{|c|}{ Available micronutrients (ppm) } \\
\hline & $\mathbf{P}$ & $\mathbf{K}$ & $\mathbf{F e}$ & Mn & n & $\mathbf{C u}$ \\
\hline 15.1 & 13.0 & 21.0 & 4.47 & 2.61 & 44 & 4.0 \\
\hline
\end{tabular}

Soil salinity treatments were prepared by mixing equal amounts of sodium chloride and calcium chloride $(\mathrm{w} / \mathrm{w}, 1: 1)$ at six rates: 0.0 (Control), 0.2, 0.4, 0.6, 0.8 and $1.0 \%$.

The seedlings were planted in $35-\mathrm{cm}$ plastic pots filled with prepared mixtures; the layout of the experiment was a complete randomized design including 6 treatments and each treatment had 3replicates. Each replicate contained 3 plants.

The plants were irrigated by mist, and after one month from transplanting all pots were supplied with kristalon (NPK 19:19:19) at the rate of $5 \mathrm{~g}$ /pot at three week interval.

Soil physical and chemical properties were analyzed using the procedures described by Black et al. (1981) and are presented in Table (A).

Data recorded: data were recorded on young trees (18 months).

\section{Growth characters}

al. (1982).

Data were statistically analyzed according to Snedecor and Cochran (1980). The least significant difference (L.S.D.) at $5 \%$ for each character was calculated.

\section{RESULTS}

\section{I. Plant Growth}

\subsubsection{Plant height (Table 1 and Fig. 1)}

The data showed that all the concentrations of soil salinity decreased significantly the plant height (ranged from 35.0 to $115.33 \mathrm{~cm}$ ) compared with the control $(133.70 \mathrm{~cm})$ in the first season. The depressing effect of salinity on plant height was more severe at higher salt concentrations $(0.8$ and $1.0 \%$ ), it caused more than $50 \%$ reduction of plant height in the first and second seasons, respectively. On the other hand, relatively lower salt concentration was less harmful to plant 
height, salinity at $0.2 \%$ caused almost 14.0 and $13.0 \%$ reduction in plant height in the first and second seasons, respectively compared to the control plants.

\subsubsection{Stem diameter (Table 1)}

Soil salinity markedly affected stem diameter especially at the higher concentrations.

The lowest salt concentration $(0.2 \%)$ slightly reduced stem diameter $(21.0$ and $20.75 \mathrm{~mm}$ in the first and second seasons, respectively) compared with the control (23.67 and $23.25 \mathrm{~mm})$. The increase in soil salinity was associated with a progressive reduction in the stem diameter in both seasons.

\subsubsection{Number of branches (Table 1)}

The effect of salinity on the number of branches / plant depended on its concentration.

The lowest concentration (0.2\%) did not have a significant effect on the number of branches as compared with the untreated plants, in both seasons of the experiment.
Increasing the concentration to $0.4 \%$ reduced the number of branches only in the first season but not in the second one. Moreover, the highest salt concentration $(1.0 \%)$ was associated with the lowest values (3.66 and 7.25 branch /plant) in the first and second seasons, respectively.

\subsubsection{Number of leaves (Table 1)}

The response of the leaf number to salinity treatments was almost similar to that observed in the branch number. The lowest salt concentration did not reduce leaf number in both seasons; whereas increasing salinity concentration resulted in a progressive decrease in leaf number.

\subsubsection{Root length (Table 1 and Fig. 2)}

Soil salinity inhibited root elongation; a progressive decrease in root length was occurred by increasing salinity concentration from $0.2 \%$ to $1.0 \%$ (except for $0.4 \%$ in the first season). The most severe inhibitory effect on root elongation was recorded by applying the highest salinity concentration (1.0\%), in both seasons.

Table (1): Effect of soil salinity on plant height $(\mathrm{cm})$, stem diameter ( $\mathrm{mm})$, number of branches, number of leaves and root length (cm) of Moring oleifera Lam.

\begin{tabular}{|c|c|c|c|c|c|c|c|c|c|c|}
\hline $\begin{array}{c}\text { Treatments } \\
\text { NaCl+CaCl } \\
(\mathbf{1} 1 \mathbf{1})\end{array}$ & \multicolumn{2}{|c|}{$\begin{array}{c}\text { Plant height } \\
(\mathbf{c m})\end{array}$} & \multicolumn{2}{|c|}{$\begin{array}{c}\text { Stem } \\
\text { diameter(mm) }\end{array}$} & \multicolumn{2}{c|}{$\begin{array}{c}\text { Number of } \\
\text { branches/plant }\end{array}$} & \multicolumn{2}{c|}{$\begin{array}{c}\text { Number of } \\
\text { leaves/plant }\end{array}$} & \multicolumn{2}{|c|}{$\begin{array}{c}\text { Root length } \\
(\mathbf{c m})\end{array}$} \\
\hline $\begin{array}{c}\text { Concentration } \\
\mathbf{\%}\end{array}$ & $\begin{array}{c}\mathbf{1}^{\text {st }} \\
\text { season }\end{array}$ & $\begin{array}{c}\mathbf{2}^{\text {nd }} \\
\text { season }\end{array}$ & $\begin{array}{c}\mathbf{1}^{\text {st }} \\
\text { season }\end{array}$ & $\begin{array}{c}\mathbf{2}^{\text {nd }} \\
\text { season }\end{array}$ & $\begin{array}{c}\mathbf{1}^{\text {st }} \\
\text { season }\end{array}$ & $\begin{array}{c}\mathbf{2}^{\text {nd }} \\
\text { season }\end{array}$ & $\begin{array}{c}\mathbf{1}^{\text {st }} \\
\text { season }\end{array}$ & $\begin{array}{c}\mathbf{2}^{\text {nd }} \\
\text { season }\end{array}$ & $\begin{array}{c}\mathbf{1}^{\text {st }} \\
\text { season }\end{array}$ & $\begin{array}{c}\mathbf{2}^{\text {nd }} \\
\text { season }\end{array}$ \\
\hline $\mathbf{0 . 0}$ & 133.70 & 159.10 & 23.67 & 23.25 & 7.33 & 10.75 & 75.67 & 81.75 & 45.00 & 46.66 \\
\hline $\mathbf{0 . 2}$ & 115.33 & 138.82 & 21.00 & 20.75 & 7.00 & 10.25 & 75.00 & 76.00 & 38.00 & 41.80 \\
\hline $\mathbf{0 . 4}$ & 104.00 & 125.60 & 17.33 & 18.25 & 5.66 & 9.79 & 63.33 & 69.50 & 44.00 & 38.42 \\
\hline $\mathbf{0 . 6}$ & 81.00 & 94.23 & 13.33 & 14.25 & 5.00 & 9.25 & 56.67 & 54.00 & 27.67 & 26.07 \\
\hline $\mathbf{0 . 8}$ & 61.22 & 80.62 & 12.67 & 13.50 & 4.66 & 8.76 & 45.00 & 46.75 & 24.67 & 22.83 \\
\hline $\mathbf{1 . 0}$ & 35.00 & 65.52 & 10.33 & 10.25 & 3.66 & 7.25 & 42.33 & 37.25 & 16.00 & 16.79 \\
\hline L.S.D at 5\% & 12.27 & 9.23 & 2.68 & 1.68 & 1.37 & 1.02 & 4.06 & 6.37 & 2.61 & 3.14 \\
\hline
\end{tabular}

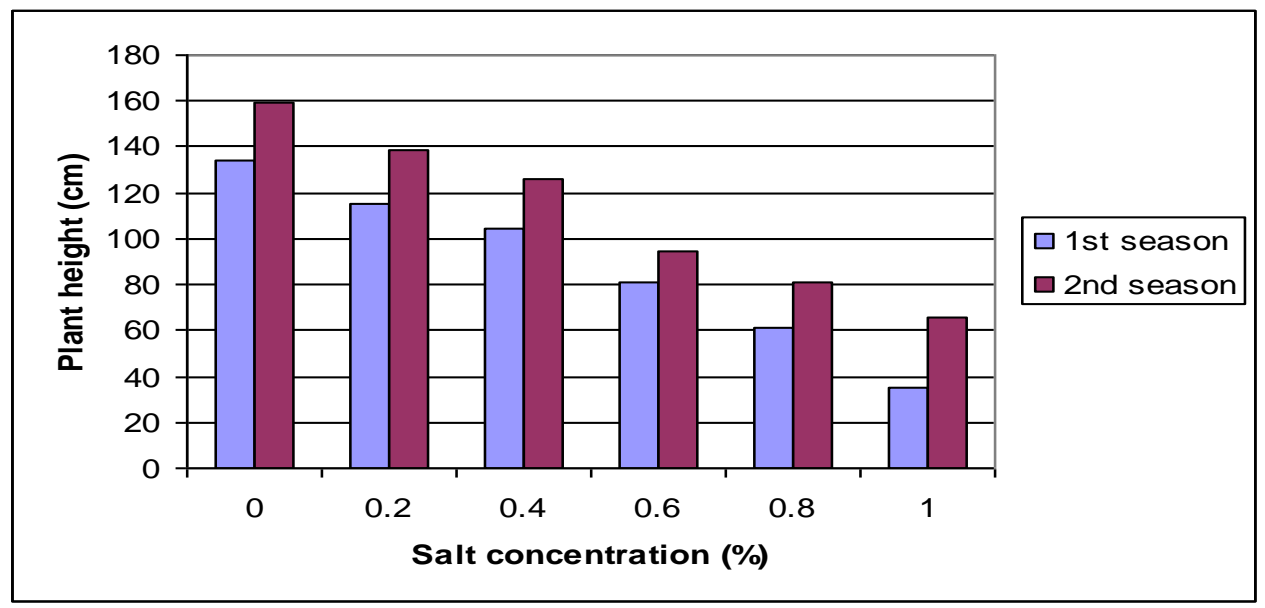

Fig.(1): Effect of soil salinity on plant height (cm) of Moringa oleifera, Lam. 


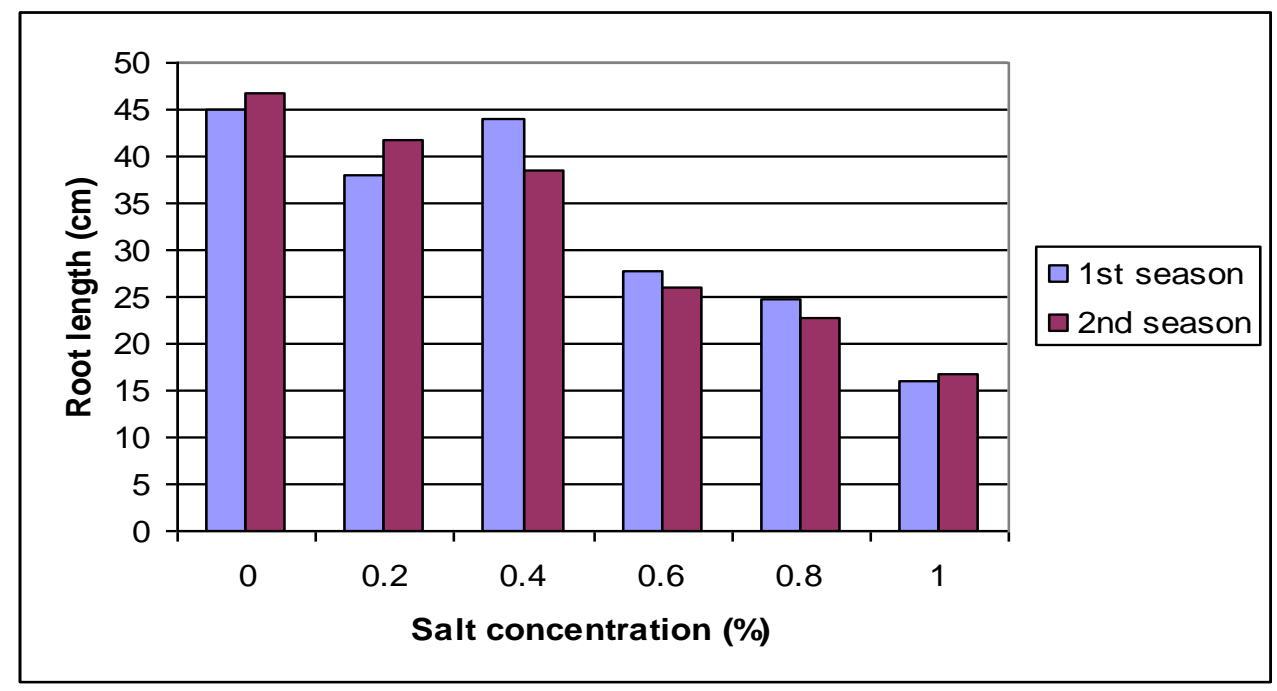

Fig.(2): Effect of soil salinity on root length (cm) of Moringa oleifera, Lam.

\subsubsection{Fresh and dry weight of shoots (Table 2)}

Soil salinity caused a decrease in shoot fresh and dry weights of Moringa oleifera in both seasons, the reduction of fresh and dry weights augmented with increasing salt concentration. The lowest salinity concentration $(0.2 \%)$ produced a slight reduction in shoot fresh weight $(6.0 \%$ and $12.0 \%$ in the first and second seasons, respectively).

Meanwhile, the highest salinity concentration had a detrimental effect on shoot fresh weight (the reductions were 74.0 and $66.0 \%$ in the first and second seasons, respectively) compared with control. A similar trend was observed for dry weight; the most serious loss (78.0 and $70.0 \%$ in the first and second seasons, respectively) occurred by applying the highest salinity concentration (1.0\%), while the lowest concentration showed a slight injurious effect.

\subsubsection{Fresh and dry weight of roots (Table 2)}

Root fresh weight decreased significantly by all salt concentrations applied (ranged from 175.7 to $359.7 \mathrm{~g}$ ) compared with the control $(385.7 \mathrm{~g})$ in the first season; the greatest reduction occurred by applying the highest salinity level (1.0\%). A similar response was observed in the second season.

The dry weight of root followed the same trend, it decreased significantly in response to all salinity concentrations as compared with the control; meanwhile, the reducible effect increased gradually with increasing salinity concentration in both seasons.

Table (2): Effect of soil salinity on fresh and dry weights of shoots and roots (gm/plant) of Moringa oleifera, Lam.

\begin{tabular}{|c|c|c|c|c|c|c|c|c|}
\hline \multirow{2}{*}{$\begin{array}{l}\text { Treatments } \\
\mathrm{NaCl}+\mathrm{CaCl}_{2(1: 1 \mathrm{w})} \\
\text { Concentration } \\
(\%)\end{array}$} & \multicolumn{2}{|c|}{$\begin{array}{l}\text { Fresh weight of } \\
\text { Shoot (gm/plant) }\end{array}$} & \multicolumn{2}{|c|}{$\begin{array}{l}\text { Dry weight of } \\
\text { Shoot }(\mathrm{gm} / \text { plant })\end{array}$} & \multicolumn{2}{|c|}{$\begin{array}{l}\text { Fresh weight of } \\
\text { root }(\mathrm{gm} / \mathrm{plant})\end{array}$} & \multicolumn{2}{|c|}{$\begin{array}{l}\text { Dry weight of } \\
\text { root (gm/plant) }\end{array}$} \\
\hline & $\begin{array}{l}1^{\text {st }} \\
\text { season }\end{array}$ & $\begin{array}{l}2^{\text {nd }} \\
\text { season }\end{array}$ & $\begin{array}{l}1^{\text {st }} \\
\text { season }\end{array}$ & $\begin{array}{l}2^{\text {nd }} \\
\text { season }\end{array}$ & $\begin{array}{l}1^{\text {st }} \\
\text { season }\end{array}$ & $\begin{array}{l}2^{\text {nd }} \\
\text { season }\end{array}$ & $\begin{array}{l}1^{\text {st }} \\
\text { season }\end{array}$ & $\begin{array}{l}2^{\text {nd }} \\
\text { season }\end{array}$ \\
\hline 0.0 & 180.40 & 203.01 & 58.83 & 71.05 & 385.70 & 398.64 & 152.63 & 169.20 \\
\hline 0.2 & 169.00 & 178.50 & 54.22 & 51.30 & 359.70 & 359.00 & 140.00 & 151.60 \\
\hline 0.4 & 114.40 & 145.20 & 35.81 & 47.04 & 344.70 & 336.53 & 129.26 & 138.00 \\
\hline 0.6 & 84.03 & 117.94 & 25.71 & 37.15 & 266.33 & 267.40 & 97.74 & 105.62 \\
\hline 0.8 & 70.54 & 79.06 & 20.81 & 24.90 & 233.33 & 229.50 & 83.16 & 88.14 \\
\hline 1.0 & 46.41 & 69.04 & 13.09 & 21.06 & 175.70 & 174.63 & 59.74 & 66.36 \\
\hline L.S.D at $5 \%$ & 6.21 & 10.31 & 4.56 & 4.18 & 7.71 & 10.23 & 5.54 & 6.48 \\
\hline
\end{tabular}




\subsection{Plant Constituents}

\subsubsection{Pigments}

\subsubsection{Chlorophylls (Table 3)}

Generally, the total chlorophyll in untreated Moringa oleifera leaves was relatively higher in the second season $(1.61 \mathrm{mg} / \mathrm{g} \mathrm{FW})$ than that determined in the first one $(1.35 \mathrm{mg} / \mathrm{g} \mathrm{FW})$. All salinity treatments decreased chlorophyll content compared with the control, although the reduction was more pronounced at the high salinity concentrations (0.8 and 1.0\%), this response was observed in both seasons.

\subsubsection{Carotenoids (Table 3)}

All salinity treatments decreased carotenoids as compared with the control in the first and second seasons, respectively. A steady decrease in carotenoids $(0.03$ or $0.04 \mathrm{mg} / \mathrm{g} \mathrm{FW})$ was recorded at each increase in salt concentration; and the lowest carotenoid contents $(0.25$ and 0.28 $\mathrm{mg} / \mathrm{g}$ FW in the first and second seasons, respectively) were recorded at the highest salt concentration $(1.0 \%)$.

Table (3): Effect of soil salinity on chlorophyll and carotenoids (mg/g. F.W) in the leaves of Moringa oleifera Lam.

\begin{tabular}{|c|c|c|c|c|}
\hline \multirow{2}{*}{$\begin{array}{l}\text { Treatments } \\
\mathrm{NaCl}+\mathrm{CaCl}_{2} \\
(1: 1 \mathrm{w})(\%)\end{array}$} & \multicolumn{2}{|c|}{$\begin{array}{c}\text { Chlorophyll } \\
\text { mg/g FW }\end{array}$} & \multicolumn{2}{|c|}{$\begin{array}{c}\text { Carotenoids } \\
\text { mg/g FW }\end{array}$} \\
\hline & $\begin{array}{c}\mathbf{1}^{\text {st }} \\
\text { seaso } \\
\mathbf{n}\end{array}$ & $\begin{array}{c}2^{\text {nd }} \\
\text { season }\end{array}$ & $\begin{array}{c}1^{\text {st }} \\
\text { season }\end{array}$ & $\begin{array}{c}2^{\text {nd }} \\
\text { season }\end{array}$ \\
\hline 0.0 & 1.35 & 1.61 & 0.42 & 0.46 \\
\hline 0.2 & 1.30 & 1.52 & 0.39 & 0.41 \\
\hline 0.4 & 1.24 & 1.47 & 0.35 & 0.37 \\
\hline 0.6 & 1.20 & 1.41 & 0.32 & 0.35 \\
\hline 0.8 & 1.15 & 1.32 & 0.28 & 0.32 \\
\hline 1.0 & 1.11 & 1.30 & 0.25 & 0.28 \\
\hline
\end{tabular}

\subsubsection{Nitrogen (Table 4)}

Nitrogen content in Moringa leaves in response to soil salinity varied according to salinity concentration, in both the first and second seasons. The lowest salinity concentration $(0.2 \%)$ induced a slight decrease in $\mathrm{N}$ content (2.36 and $3.05 \%$ compared with 2.40 and 3.13 in control in the first and second seasons, respectively). On the other hand, increasing salinity concentration was associated with a gradual reduction in $\mathrm{N}$ content, and the strongest reduction $(0.63$ and $0.54 \%$ in the first and second seasons, respectively) occurred in response to the highest salinity concentration $(1.0 \%)$.

The response of nitrogen content of stem to salinity was similar to that observed in leaf $\mathrm{N}$ content; a slight reduction occurred by applying the lowest salinity concentration and augmented with increasing salinity concentration. $\mathrm{N}$ content in roots also decreased in response to salinity treatment, especially at the higher concentrations.

\subsubsection{Phosphorus (Table 5)}

Generally, $\mathrm{P}$ content in the leaves, stems and roots of Moringa oleifera was relatively lower than $\mathrm{N}$ content. In the first season, all salinity treatments caused a gradual decrease in $\mathrm{P}$ content of the leaves, stems and roots which reached their minimal values $(0.07,0.05$, and $0.05 \%$, respectively) in response to the highest salinity level $(1.0 \%)$. In the second season, $\mathrm{P}$ content of the leaves, stems and roots gradually decreased by applying all salinity levels; whereas $\mathrm{P}$ contents of stems and roots were slightly reduced by applying the lowest salinity concentration $(0.2 \%)$, and the reducible effect increased with increasing salinity concentration.

\subsubsection{Potassium (Table 6)}

Soil salinity at the lower concentration $(0.2 \%)$ produced a slight decrease in $\mathrm{K}$ content in leaf and stem (the decrease did not exceed 0.07 and $0.08 \%$ in the first and second seasons, respectively). Increasing salt concentrations were associated with a gradual decrease in $\mathrm{K}$ content which reached its minimal values (1.98 and $1.71 \%$ in the leaf and stem, respectively) at the highest salt concentration $(1.0 \%)$ in the first season, and a similar response was observed in the second season. Potassium content in the roots was relatively lower than $\mathrm{K}$ content in either leaf or stem. The mean values* of $\mathrm{K}$ content of untreated plants were 2.41 and $2.15 \%$ in the leaf and stem, respectively compared to only $1.54 \%$ in the roots. A similar pattern was exhibited by treated plants. The response of $\mathrm{K}$ content of the roots to salinity followed the same trend described for the leaves and stem.

\subsubsection{Sodium (Table 7)}

Root $\mathrm{Na}$ content was generally higher than leaf or stem contents in both treated and untreated (control) plants. Soil salinity increased Na content in the leaf, stem and root of Moringa, and the increase was positively correlated with salt concentration in both seasons.

Plants subjected to the highest salinity concentration showed the maximum mean value (of both seasons) of $\mathrm{Na}$ in the roots $(0.5 \%)$ compared to that recorded in the stem $(0.27 \%)$ or leaves $(0.21 \%)$. Similarly, Na content in roots of untreated plants reached a higher mean value $(0.24 \%)$ than $\mathrm{Na}$ content in the leaves and stem (0.07 and $0.10 \%$, respectively) 
Table (4): Effect of soil salinity on nitrogen content in the leaves, stems and roots of Moringa oleifera, Lam.

\begin{tabular}{|c|c|c|c|c|c|c|}
\hline \multirow{3}{*}{$\begin{array}{l}\text { Treatments } \\
\mathrm{NaCl}+\mathrm{CaCl}_{2} \\
(1: 1 \mathrm{w})(\%)\end{array}$} & \multicolumn{6}{|c|}{ Nitrogen \% DW } \\
\hline & \multicolumn{2}{|c|}{ Leaves } & \multicolumn{2}{|c|}{ Stems } & \multicolumn{2}{|c|}{ Roots } \\
\hline & $\begin{array}{c}1^{\text {st }} \\
\text { season }\end{array}$ & $\begin{array}{c}2^{\text {nd }} \\
\text { season }\end{array}$ & $\begin{array}{c}1^{\text {st }} \\
\text { season }\end{array}$ & $\begin{array}{c}2^{\text {nd }} \\
\text { season }\end{array}$ & $\begin{array}{c}1^{\text {st }} \\
\text { season }\end{array}$ & $\begin{array}{c}2^{\text {nd }} \\
\text { season }\end{array}$ \\
\hline 0.0 & 2.40 & 3.13 & 1.42 & 1.66 & 1.12 & 1.36 \\
\hline 0.2 & 2.36 & 3.05 & 1.36 & 1.56 & 1.10 & 1.31 \\
\hline 0.4 & 2.23 & 2.98 & 1.28 & 1.38 & 1.06 & 1.25 \\
\hline 0.6 & 2.15 & 2.87 & 1.15 & 1.24 & 1.00 & 1.18 \\
\hline 0.8 & 1.99 & 2.70 & 1.08 & 1.13 & 0.91 & 1.12 \\
\hline $\mathbf{1 . 0}$ & 1.77 & 2.59 & 0.96 & 1.05 & 0.86 & 1.08 \\
\hline
\end{tabular}

Table (5): Effect of soil salinity on phosphorus content in the leaves, stems and roots of Moringa oleifera, Lam.

\begin{tabular}{|c|c|c|c|c|c|c|}
\hline \multirow{2}{*}{$\begin{array}{c}\text { Treatments } \\
\text { NaCl+CaCl } \\
(\mathbf{1 : 1 w ) ( \% )}\end{array}$} & \multicolumn{2}{|c|}{ Leaves } & \multicolumn{2}{c|}{ Stems } & \multicolumn{2}{c|}{ Roots } \\
\cline { 2 - 7 } & $\begin{array}{c}\mathbf{1}^{\text {st }} \\
\text { season }\end{array}$ & $\begin{array}{c}\mathbf{2}^{\text {nd }} \\
\text { season }\end{array}$ & $\begin{array}{c}\mathbf{1}^{\text {st }} \\
\text { season }\end{array}$ & $\begin{array}{c}\mathbf{2}^{\text {nd }} \\
\text { season }\end{array}$ & $\begin{array}{c}\mathbf{1}^{\text {st }} \\
\text { season }\end{array}$ & $\begin{array}{c}\mathbf{2}^{\text {nd }} \\
\text { season }\end{array}$ \\
\hline $\mathbf{0 . 0}$ & 0.18 & 0.25 & 0.18 & 0.22 & 0.15 & 0.18 \\
\hline $\mathbf{0 . 2}$ & 0.17 & 0.18 & 0.16 & 0.20 & 0.13 & 0.16 \\
\hline $\mathbf{0 . 4}$ & 0.14 & 0.17 & 0.14 & 0.16 & 0.11 & 0.15 \\
\hline $\mathbf{0 . 6}$ & 0.12 & 0.13 & 0.11 & 0.13 & 0.10 & 0.11 \\
\hline $\mathbf{0 . 8}$ & 0.11 & 0.12 & 0.09 & 0.12 & 0.07 & 0.09 \\
\hline $\mathbf{1 . 0}$ & 0.07 & 0.10 & 0.05 & 0.09 & 0.05 & 0.07 \\
\hline
\end{tabular}

Table (6): Effect of soil salinity on potassium content in the leaves, stems and roots of Moringa oleifera, Lam.

\begin{tabular}{|c|c|c|c|c|c|c|}
\hline \multirow{2}{*}{$\begin{array}{c}\text { Treatments } \\
\text { NaCl + } \begin{array}{c}\text { CaCl } \\
(\mathbf{\%})\end{array}\end{array}$} & \multicolumn{6}{|c|}{ Potassium \% DW } \\
\cline { 2 - 7 } & \multicolumn{2}{|c|}{ Leaves } & \multicolumn{2}{c|}{ Stems } & \multicolumn{2}{c|}{ Roots } \\
\cline { 2 - 7 } & $\begin{array}{c}\mathbf{1}^{\text {st }} \\
\text { season }\end{array}$ & $\begin{array}{c}\mathbf{2}^{\text {nd }} \\
\text { season }\end{array}$ & $\begin{array}{c}\mathbf{1}^{\text {st }} \\
\text { season }\end{array}$ & $\begin{array}{c}\mathbf{2}^{\text {nd }} \\
\text { season }\end{array}$ & $\begin{array}{c}\mathbf{1}^{\text {st }} \\
\text { season }\end{array}$ & $\begin{array}{c}\mathbf{2}^{\text {nd }} \\
\text { season }\end{array}$ \\
\hline $\mathbf{0 . 0}$ & 2.38 & 2.44 & 2.12 & 2.18 & 1.42 & 1.66 \\
\hline $\mathbf{0 . 2}$ & 2.31 & 2.40 & 2.04 & 2.13 & 1.40 & 1.63 \\
\hline $\mathbf{0 . 4}$ & 2.25 & 2.32 & 1.98 & 2.06 & 1.36 & 1.58 \\
\hline $\mathbf{0 . 6}$ & 2.16 & 2.22 & 1.87 & 2.0 & 1.31 & 1.54 \\
\hline $\mathbf{0 . 8}$ & 2.08 & 2.13 & 1.80 & 1.96 & 1.27 & 1.49 \\
\hline $\mathbf{1 . 0}$ & 1.98 & 2.05 & 1.71 & 1.88 & 1.21 & 1.43 \\
\hline
\end{tabular}

* Mean of two seasons

Table (7): Effect of soil salinity on sodium content in the leaves, stems and roots of Moringa oleifera, Lam.

\begin{tabular}{|c|c|c|c|c|c|c|}
\hline \multirow{3}{*}{$\begin{array}{c}\text { Treatments } \\
\mathrm{NaCl}+\mathrm{CaCl}_{2}(1: 1 \mathrm{w}) \\
(\%)\end{array}$} & \multicolumn{6}{|c|}{ Sodium \% DW } \\
\hline & \multicolumn{2}{|c|}{ Leaves } & \multicolumn{2}{|c|}{ Stems } & \multicolumn{2}{|c|}{ Roots } \\
\hline & $\begin{array}{c}1^{\text {st }} \\
\text { season }\end{array}$ & $\begin{array}{c}2^{\text {nd }} \\
\text { season }\end{array}$ & $\begin{array}{c}1^{\text {st }} \\
\text { season }\end{array}$ & $\begin{array}{c}2^{\text {nd }} \\
\text { season }\end{array}$ & $\begin{array}{c}1^{s t} \\
\text { season }\end{array}$ & $\begin{array}{c}2^{\text {nd }} \\
\text { season }\end{array}$ \\
\hline 0.0 & 0.06 & 0.09 & 0.09 & 0.11 & 0.22 & 0.26 \\
\hline 0.2 & 0.08 & 0.11 & 0.13 & 0.16 & 0.27 & 0.30 \\
\hline 0.4 & 0.10 & 0.14 & 0.15 & 0.19 & 0.31 & 0.36 \\
\hline 0.6 & 0.13 & 0.16 & 0.18 & 0.23 & 0.35 & 0.42 \\
\hline 0.8 & 0.17 & 0.19 & 0.22 & 0.26 & 0.40 & 0.48 \\
\hline 1.0 & 0.20 & 0.23 & 0.25 & 0.30 & 0.48 & 0.52 \\
\hline
\end{tabular}




\section{DISCUSSION}

The presented results showed that increasing salinity levels reduced all growth parameters of Moringa oleifera at an early growth stage.

Relatively low salt concentration slightly decreased plant height and stem diameter but did not affect leaf and branch number. Previous studies showed that low salinity levels did not reduce growth in many other tree species such as Erythrina variegata at the seedling stage (Muthuchelian et al., 1996); and even stimulated growth of some tree species, low salt concentration stimulated growth of Eucalyptus camadulensis and Dalbergia sisso (Rawat and Banerjee, 1998); also stem and root elongation of Cassia montana were stimulated by salt at low concentration (Patel and Pandey, 2007).

Moreover, increasing salinity decreased plant height, stem diameter, number of branches, number of leaves and root length of Moringa oleifera, which coincides with previous reports on Albezia lebbeck and Melia azederach as their seedling growth was adversely affected by the increase in salinity (Yadav et al., 2005). It was suggested that high salinity levels decrease plant height as well as shoot and root biomass which is attributed to the decrease of water and osmotic potentials of plants under saline conditions (Villagra and Cavagnaro, 2005).

Generally, it was admitted that, salinity reduces the ability of plants to take up water which rapidly causes reduction in growth rate; but recently it was suggested that the reduction in shoot growth is probably due to hormonal signals generated by the roots (Munns, 2002).

The present results showed that high salinity level had a detrimental effect on dry weight of shoot and root. Similar observations were previously reported on Prosopis cineraria (Ramoliya et al., 2006), and on Cassia angustifolia (Agarwal and Pandey, 2004).

Chlorophyll and carotenoids were affected by salinity, and decreased steadily with increasing salt concentration. Similar responses were previously observed in other tree species; high salinity caused a decrease in pigment content of Erythrina variegata (Muthuchelian et al., 1996), a reduction in chlorophyll concentration of Eucalyptus camadulensis (Rawat and Banerjee, 1998) and Moringa oleifera (Valia et al., 1993).

The determination of mineral elements in leaves, stem and roots of Moringa oleifera in the present study demonstrated the following findings:
- Generally, leaf, stem and root contents of $\mathrm{N}$ and $\mathrm{K}$ are relatively higher than $\mathrm{P}$ and $\mathrm{Na}$ contents.

- Na content in the root is relatively higher than Na content in leaf and stem, which may be attributed to the displacement of $\mathrm{Ca}^{+2}$ by $\mathrm{Na}^{+}$from membrane sites in root hair (Cramer et al., 1985).

- Increasing soil salinity reduced N, P and K contents in leaf, stem and root; and the highest salinity level resulted in the greatest reducing effect. These observations are in agreement with previous ones on Prosopis cineraria which responded to salt stress by a decrease in $\mathrm{N}$ and $\mathrm{P}$ content in leaf, stem and root (Ramoliya et al.,2006).

In view of the present results on Moringa oleifera, it can be concluded that the juvenile tree can be grown successfully under low salinity levels; but cannot tolerate high salinity levels during this stage of growth. Further studies on salt tolerance of Moringa oleifera tree at later stages of development are suggested to provide more information that may allow extending the cultivation of this valuable tree in a moderately saline land.

\section{REFERENCES}

Agarwal S. and Pandey V. (2004). Antioxidant enzyme responses to $\mathrm{NaCl}$ stress in Cassia angustifolia. Biologia-Plantarum., 48(4): 555560.

Black C. A., Evans D. D., Ensminger L. E., White G. L. and Clark F. E. (1981). Methods of Soil Analysis. Part 2, pp: 1-100, Agron. Inc. Madison. Wisc., USA.

Chapman H.D. and Pratt P. (1961). Methods of analysis of soil and water. Univ. of Calif., Div. Agric. Sci., U.S.A. $2^{\text {nd }}$ Ed Chapter, 17, pp: 150-161.

Cottenie A., Verloo M., Kiekens L., Velghe G. and Camerlynck R. (1982). Chemical Analysis of Plant and Soil. Laboratory of Analytical and Agro chemistry, State Univ. Chemical . Ghent. Belgium, pp: 100-129.

Cramer G. R., Lauchli A. and Epstein E. (1985). Displacement of $\mathrm{Ca}^{+2}$ by $\mathrm{Na}^{+}$from the Plasmalemma of root cells. A primary response to salt stress. Plant Physiol., 79: 207- 211.

Meitzner L. and Price M. (1996). Amaranthe to Zai Holes: Ideas for growing food under difficult conditions, ECHO, North Fort Myers, Florida. 
Morton J. F. (1991). The horseradish tree, Moringa pterygosperma (Moringaceae) a boon to arid lands. Econ. Bot., 45: 318-333.

Munns R. (2002). Comparative physiology of salt and water stress. Plant Cell Environ., 25: 239250 (C.F. CAB International).

Muthuchelian K., Murugan C., Harigovindan R., Nedunchezhian N. and Kulandaivelu G. (1996). Ameliorating effect of triacontanol on salt stressed Erythrina variegate seedlings. Changes in growth, biomass, pigments and solute accumulation. Biologia Plantarum., 38(1): 133-136.

Nornai R. (1982). Formula for determination of chlorophyllus pigments extracted with $\mathrm{N}, \mathrm{N}$ dimethyl formamide. Plant Physiol., 69:13761381.

Patel A. D. and Pandey A. N. (2007). Effect of soil salinity on growth, water status and nutrient accumulation in seedlings of Cassia montana (Fabaceae). Journal of Arid Environments., 70 (1): 174-182.

Pregl F. (1945). Quantitative Organic Microanalysis . $4^{\text {th }}$ English ed., P.19. London: J. \& A.Churchill, Ltd.

Ramachandran C., Peter, K. V. and Gopalakrishnan, P. K. (1980). Drumstick (Moringa oleifera): a multipurpose Indian vegetable. Econ. Bot., 34: 276-283.

Ramoliya P. J., Patel H. M. , Joshi J. B. and Pandey A. N. (2006). Effect of salinization of soil on growth and nutrient accumulation in seedlings of Prosopis cineraria. Journal of Plant Nutrition., 29(2): 283-303.
Rawat J. S and Banerjee S. P. (1998). The influence of salinity on growth, biomas production and photosynthesis of Eucalyptus camaldulensis, Dehnh. And Dalbergia sissoo Roxb; seedlings. Plant and Soil., 205(2): 163169.

Snedecor G.W. and Cochran W.G. (1980). Statistical Methods $7^{\text {th }}$ ed, Iowa State Univeresity Press, Iowa, 507 p.

Snell F. D. and Snell C.T. (1949). Colorimetric methods of analysis. $3^{\text {rd }}$ Ed. P.D.Van. Nostrand Comp. Inc. New York.

Sutherland J. P., Folkard G. K. and Grant W. D. (1989). Seeds of Moringa species as naturally occurring flocculants for water treatment. Science Technology and Development, 7 (3): 191-197.

Valia R. Z., Patil V. K, Patel Z. N. and Kapadia P. K. (1993). Physiological responses of drumstick (Moringa oleifera, Lamk.) to varying levels of ESP. Indian Journal of Plant Physiology, 36(4): 261-262.

Villagra P. E. and Cavagnaro J. B. (2005). Effects of salinity on the establishment and early growth of Prosopis argentina and Prosopis alpataco seedlings in two contrasting soils: implications for their ecological success. Austral. Ecology, 30(3): 325-335.

Yadav B. S., Kumar R. and Kumar N. (2005). Effect of soil salinity on germination and seedling growth of Albizia lebbeck (L.) Benth. and Melia azedarach L. Indian Journal of Forestry, 28(2): 132-135.

\footnotetext{
"Moringa oleifera" تأثير الملوحة على النمو والمكونات الكيماوية لنبات المورنجا أوليفيرا

رفيعة سعد الدين الضبع- عحم عبد الخالق الخطيب- عزة عبد الحميد عحم مظهر *ـ أحمد عبد البديع السبد*

قسم بساتين الزينة- كلية الزر اعة- جامعة القاهرة

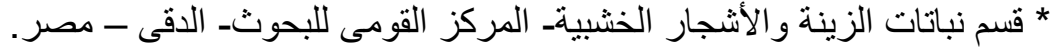

ملخص

تزر ع أثجار المورنجا لقيمتها العاليه حيث أن جميع أجزاء الثجرة وتشمل البذرة و الساق والأفرع والأوراق

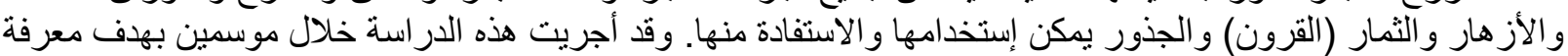

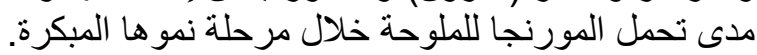

زر عت شتلات المورنجا فى أصص بداخل الصوبة وذلك بمحطة البحوث و الانتاج بالنوبارية و إثتملت التجربة على 6 ولى 6

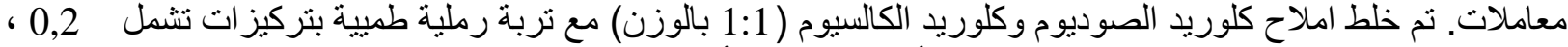

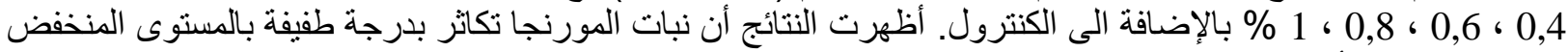

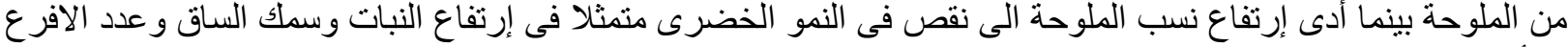
و الأوراق وطول الجذور. كذلك تسبب إرتفاع الملوحة فى نقص الوزن الطازج و الجاف للنبات، ونقص الكلوروفيل
} 
و الكاروتينيدات. تأثرت أيضا نسب النيتروجين و الفوسفور و البوتاسيوم حيث إنخفضت في جميع أجزاء النبات بزيادة الملوحة.

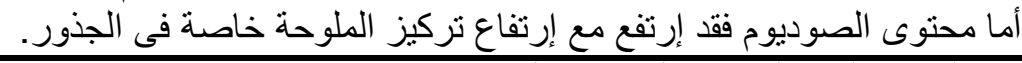

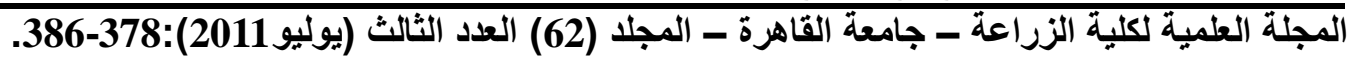

